\title{
Tirmania pinoyi: chemical composition, in vitro antioxidant and antibacterial activities and in situ control of Staphylococcus aureus in chicken soup
}

Dejan Stojković ${ }^{1}$, Filipa S. Reis ${ }^{2}$, Isabel C.F.R. Ferreira, ${ }^{2, *}$, Lillian Barros ${ }^{2}$, Jasmina Glamočlija ${ }^{1}$, Ana Ćirić ${ }^{1}$, Miloš Nikolić ${ }^{1}$, Tanja Stević ${ }^{3}$, Abdulhamed Giveli ${ }^{4}$, Marina Soković ${ }^{1, *}$

${ }^{1}$ Institute for Biological Research "Siniša Stanković", University of Belgrade, Bulevar Despota Stefana 142, 11000 Belgrade, Serbia

${ }^{2}$ CIMO-ESA, Polytechnic Institute of Bragança, Campus de Santa Apolónia, Ap. 1172, 5301-855 Bragança, Portugal

${ }^{3}$ Institute for Medicinal Plant Research “Dr Josif Pančić”, Tadeuša Košćuška 1, 11000 Belgrade, Serbia

${ }^{4}$ Department of Botany, Faculty of Science, University of Al-Gabel Al-Garbe, Zintan, Libya

* Authors to whom correspondence should be addressed (Isabel C.F.R. Ferreira; e-mail: iferreira@ipb.pt; telephone +351-273-303219; fax +351-273-325405 and Marina D. Soković; e-mail: mris@ibiss.bg.ac.rs; telephone +381-11-2078419; fax +381-112761433). 


\begin{abstract}
Desert truffle, Tirmania pinoyi (Maire) Malençon from Libya was chemically characterized in nutritional value, primary and secondary metabolites. Antioxidant (scavenging activity, reducing power and inhibition of lipid peroxidation) and antibacterial activity of its methanolic extract alone and in combination with potassium metabisulfite (E224) were evaluated under in vitro conditions. Furthermore, the effect of the extract on the control of Staphylococcus aureus was examined in a contaminated soup under in situ conditions. T. pinoyi was showed to be rich in carbohydrates $(82.60 \mathrm{~g} / 100 \mathrm{~g}$ $\mathrm{dw})$ and proteins $(8.06 \mathrm{~g} / 100 \mathrm{~g} \mathrm{dw})$, being identified four free sugars (rhamnose, fructose, trehalose and mannitol) and three tocopherol isoforms $(\beta-, \delta$ - and $\gamma$-tocopherols). Oleic (32.29\%), linoleic $(29.72 \%)$ and palmitic $(27.97 \%)$ acids were the main fatty acids. $p$ Hydroxybenzoic $(300.65 \mu \mathrm{g} / 100 \mathrm{~g} \mathrm{dw})$ and cinnamic $(8.30 \mu \mathrm{g} / 100 \mathrm{~g} \mathrm{dw})$ acids were quantified, as also four organic acids: quinic $(0.83 \mathrm{~g} / 100 \mathrm{~g} \mathrm{dw})$, malic $(0.35 \mathrm{~g} / 100 \mathrm{~g} \mathrm{dw})$, fumaric $(0.05 \mathrm{~g} / 100 \mathrm{~g} \mathrm{dw})$ and citric $(1.26 \mathrm{~g} / 100 \mathrm{~g} \mathrm{dw})$ acids. The methanolic extract of the mushroom showed in vitro antioxidant and antimicrobial activities. Sterilized distillated water containing $0.02 \%$ Tween 80 proved to be the most convenient solvent for in situ antimicrobial activity; the extract successfully inhibited the growth of S. aureus in chicken soup in a dose dependent manner.
\end{abstract}

Keywords: Tirmania pinoyi; chemical composition; antioxidant; antimicrobial; chicken soup. 


\section{Introduction}

'Desert truffle' is a term used to refer members of the genera Terfezia and Tirmania in the family Terfeziaceae, order Pezizales. They are edible mycorrhizal fungi, mostly endemic to arid and semi-arid areas of the Mediterranean Region, Arabian Peninsula and North-Africa; some of them have been found in South Africa and China. They are socioeconomically important fungi and are widely consumed in North Africa (Algeria, Morocco, Tunisia and Egypt) and in the Middle East (Saudi Arabia, Kuwait, Iraq, Iran, Lebanon, Syria and Jordon). The desert truffle is not so strongly flavored when compared with the European truffles; nevertheless, it is a type of mushroom highly prized for its unique musky flavor (Diez, Manjon \& Martin, 2002; Shavit \& Volk, 2007; Dib-

\section{Bellahouel \& Fortas, 2011).}

In good seasons, desert truffles are dried and ground to powder to supplement the regular diet. Even though the unique aroma of the truffles cannot be preserved by drying, the nutritious flour is added to a mixture of flatbread, which is then baked and eaten with honey. In times of famine, people have been known to rely on truffles. Traditionally, desert truffles are cooked simply, so as not to mask their delicate aroma. The oldest way, which is still very popular today, is to roast them in the embers of the fire. Truffles are also baked, sliced and fried in butter. They are made into fragrant soups, usually with camel's milk (Shavit \& Volk, 2007). A very popular dish, served at souks and restaurants all over the Middle East, is scrambled eggs with desert truffles, served in a pita-pocket (Shavit \& Volk, 2007). Popularity of desert truffles is due to their nutritional value and delicious taste. Several studies on their chemical composition have shown that they are rich in proteins, amino acids, fiber, fatty acids, minerals and carbohydrates (Bokhary \& 
Parvez, 1992; Hussain \& Al-Ruqaie, 1999; Dabbour \& Takruri, 2002; Murcia et al., 2003; Yildiz, Yesil, Yavuz \& Karakaplan, 2005). The protein content, which averages $20 \%$ of the dry weight in desert truffles, is significantly higher than in most vegetables and other fungi and, therefore, the consumption of these truffles is recommended (Murcia et al., 2003). Desert truffles (Tirmania pinoyi, T. nivea, Terfezia claveryi, Picoa juniperi) comprise a vast unexploited source of therapeutic compounds with anti-inflammatory, immunesuppressor, antimutagenic and anticarcinogenic potential (Hannan, Al-Dakan, Aboul-Enein \& Al-Othaimeen, 1989), and antioxidant properties (Murcia et al., 2002; Pervez-Gilabert, Sanchez-Felipe \& Garcia-Carmona, 2005; Al-Laith, 2010). Furthermore, the presence of enzymes (esterase, lipoxygenases) with great interest was found in the ascocarps of some desert truffles (Pervez-Gilabert, Sanchez-Felipe \& Garcia-Carmona, 2005). A promising antimicrobial activity has been detected for some species of desert truffles, Terfezia boudieri (Rougieux, 1963), and Terfezia claveryi (Janakat, Al-Fakhiri \& Sallal, 2005). Antibacterial activity of various fractions of ethyl acetate extract from Tirmania pinoyi was recently investigated (Dib-Bellahouel \& Fortas, 2011).

The aim of this study was to characterize chemical and bioactive properties of Tirmania pinoyi from Libya. For that, it was determined the: i) nutritional value and chemical composition (free sugars, fatty acids, tocopherols, organic acids and phenolic compounds) of fruiting bodies; ii) in vitro antioxidant (scavenging activity, reducing power and lipid peroxidation inhibition) and antibacterial (against food poisoning and food spoilage bacteria) activities of its methanolic extract; iii) the extract effect on the inhibition of spoilage food microorganism in situ, after incorporation in soup since desert 
truffles are widely used in Libyan traditional soup. The proposed research evaluates the possibility of using natural extracts as food preservatives.

\section{Material and methods}

\subsection{Mushroom species}

Tirmania pinoyi (Maire) Malençon fruiting bodies were collected from Kashem Alanf, Al-Hamada 160 km southern Zintan, in Libya (30O 27'52.63 N 110 26'41.85 N), during March of 2012, and authenticated by Dr. Jasmina Glamočlija (Institute for Biological Research). A voucher specimen was deposited at the Fungal Collection Unit of the Mycological Laboratory, Department for Plant Physiology, Institute for Biological Research "Siniša Stanković", Belgrade, Serbia, with the number Tp-009-2011. The samples to be analyzed were lyophilized (LH Leybold, Lyovac GT2, Frenkendorf, Switzerland) and powdered.

\subsection{Standards and reagents}

Acetonitrile $99.9 \%, n$-hexane $95 \%$ and ethyl acetate $99.8 \%$ were of HPLC grade from Fisher Scientific (Lisbon, Portugal). The fatty acids methyl ester (FAME) reference standard mixture 37 (standard 47885-U) was purchased from Sigma (St. Louis, MO, USA), as also other individual fatty acid isomers, sugars (D(-)-fructose, $\mathrm{D}(-)$-mannitol, $\mathrm{D}(+)$-raffinose pentahydrate, $\mathrm{L}(+)$-rhamnose monohydrate and $\mathrm{D}(+)$-trehalose) and tocopherols $(\alpha-, \beta-, \gamma$-, and $\delta$-isoforms) standards. Racemic tocol, $50 \mathrm{mg} / \mathrm{mL}$, was purchased from Matreya (PA, USA). 2,2-Diphenyl-1-picrylhydrazyl (DPPH) was obtained from Alfa Aesar (Ward Hill, MA, USA). Phenolic standards ( $p$-hydroxybenzoic 
acid and cinnamic acids) and trolox (6-hydroxy-2,5,7,8-tetramethylchroman-2-carboxylic acid) were purchased from Sigma (St. Louis, MO, USA). Methanol and all other chemicals and solvents were of analytical grade and purchased from common sources. Water was treated in a Milli-Q water purification system (TGI Pure Water Systems, USA). Mueller-Hinton agar (MH) and malt agar (MA) were obtained from the Institute of Immunology and Virology, Torlak (Belgrade, Serbia). Phosphate buffered saline (PBS) was obtained from Sigma Chemical Co. (St. Louis, USA).

\subsection{Chemical characterization of Tirmania pinoyi fruiting bodies}

2.3.1. Nutritional value. The lyophilized samples were analysed for moisture, proteins, fat, carbohydrates and ash, using the AOAC procedures (AOAC, 1995). The crude protein content $(\mathrm{N} \times 4.38)$ of the samples was estimated by the macro-Kjeldahl method; the crude fat was determined by extracting a known weight of powdered sample with petroleum ether, using a Soxhlet apparatus; the ash content was determined by incineration at $600 \pm 15{ }^{\circ} \mathrm{C}$. Total carbohydrates were calculated by difference. Energy was calculated according to the following equation: Energy $(\mathrm{kJ})=17 \times(\mathrm{g}$ proteins $+\mathrm{g}$ carbohydrates $)+37 \times(\mathrm{g}$ fat $)$.

2.3.2. Free Sugars composition. The lyophilized samples $(1 \mathrm{~g})$ were spiked with the Internal Standard, IS (raffinose, $5 \mathrm{mg} / \mathrm{mL}$ ), and were extracted with $40 \mathrm{~mL}$ of $80 \%$ aqueous ethanol at $80{ }^{\circ} \mathrm{C}$ for $1 \mathrm{~h} 30 \mathrm{~min}$. The resulting suspension was filtered and concentrated under reduced pressure (rotary evaporator Büchi R-210) and defatted three times with $10 \mathrm{~mL}$ of ethyl ether, successively. After concentration, the residues were 
dissolved in water to a final volume of $5 \mathrm{~mL}$, filtered through a $0.22 \mu \mathrm{m}$ disposable $\mathrm{LC}$ filter disk, transferred into an injection vial and analysed by High Performance Liquid Chromatography (HPLC) system consisted of an integrated system with a pump (Knauer, Smartline system 1000), degasser system (Smartline manager 5000) and auto-sampler (AS-2057 Jasco), coupled to a refraction index detector (RI detector Knauer Smartline 2300). The chromatographic separation was achieved with an Eurospher 100-5 $\mathrm{NH}_{2}$ column $\left(4.6 \mathrm{~mm} \times 250 \mathrm{~mm}, 5 \mathrm{~mm}\right.$, Knauer) operating at $35^{\circ} \mathrm{C}$ (7971R Grace oven). The mobile phase used was acetonitrile/deionized water, 70:30 (v/v) at a flow rate of 1 $\mathrm{mL} / \mathrm{min}$, and the injection volume was $20 \mu \mathrm{L}$ (Reis et al., 2011). Sugars identification was made by comparing the relative retention times of sample peaks with standards. Data were analyzed using Clarity 2.4 Software (DataApex). Quantification was based on the RI signal response of each standard, using the IS method and by using calibration curves obtained from commercial standards of each compound. The results were expressed in $g$ per $100 \mathrm{~g}$ of dry weight.

2.3.3. Tocopherols composition. BHT solution (100 $\mu \mathrm{L}$ ) and IS solution (tocol, $250 \mu \mathrm{L}$ ) were added to the sample prior to the extraction procedure. The lyophilized samples ( $\sim 500 \mathrm{mg})$ were homogenized with methanol $(4 \mathrm{~mL})$ by vortex mixing $(1 \mathrm{~min})$. Subsequently, hexane $(4 \mathrm{~mL})$ was added and again vortex mixed for $1 \mathrm{~min}$. After that, saturated $\mathrm{NaCl}$ aqueous solution $(2 \mathrm{~mL})$ was added, the mixture was homogenized (1 min), centrifuged (5 min, 4000g) and the clear upper layer was carefully transferred to a vial. The sample was re-extracted twice with hexane. The combined extracts were taken to dryness under a nitrogen stream, redissolved in $1 \mathrm{~mL}$ of hexane, dehydrated with 
anhydrous sodium sulphate, filtered through a $0.22 \mu \mathrm{m}$ disposable LC filter disk, transferred into a dark injection vial and analysed by HPLC (equipment described above), and a fluorescence detector (FP-2020; Jasco) programmed for excitation at $290 \mathrm{~nm}$ and emission at $330 \mathrm{~nm}$. Data were analysed using Clarity 2.4 Software (DataApex). The chromatographic separation was achieved with a Polyamide II $(250 \times 4.6 \mathrm{~mm})$ normalphase column from YMC Waters (Japan) operating at $35^{\circ} \mathrm{C}$. The mobile phase used was a mixture of hexane and ethyl acetate $(70: 30, \mathrm{v} / \mathrm{v})$ at a flow rate of $1 \mathrm{ml} / \mathrm{min}$, and the injection volume was $20 \mu \mathrm{L}$ (Heleno, Barros, Sousa, Martins \& Ferreira, 2010). The compounds were identified by chromatographic comparisons with authentic standards. Quantification was based on the fluorescence signal response of each standard, using the IS method and by using calibration curves obtained from commercial standards of each compound. The results were expressed in $\mu \mathrm{g}$ per $100 \mathrm{~g}$ of dry weight.

2.3.4. Fatty acids composition. Fatty acids were determined after a transesterification procedure performed with the oil obtained by soxhlet extraction: fatty acids were methylated with $5 \mathrm{~mL}$ of methanol:sulphuric acid:toluene 2:1:1 (v:v:v), during at least 12 $\mathrm{h}$ in a bath at $50{ }^{\circ} \mathrm{C}$ and $160 \mathrm{rpm}$; then $3 \mathrm{~mL}$ of deionized water were added, to obtain phase separation; the FAME (fatty acids methyl esters) were recovered with $3 \mathrm{~mL}$ of diethyl ether by shaking in vortex, and the upper phase was dried with sodium sulphate anhydrous; the sample was recovered in a vial with Teflon, and before injection the sample was filtered with $0.2 \mu \mathrm{m}$ nylon filter from Milipore. The analysis was performed using a gas chromatographer (DANI 1000) equipped with a split/splitless injector and a flame ionization detector (GC-FID) and a Macherey-Nagel column $(30 \mathrm{~m} \times 0.32 \mathrm{~mm}$ ID 
$\times 0.25 \mu \mathrm{m} d_{f}$ ). The oven temperature program was as follows: the initial temperature of the column was $50{ }^{\circ} \mathrm{C}$, held for $2 \mathrm{~min}$, then a $30^{\circ} \mathrm{C} / \mathrm{min}$ ramp to $125^{\circ} \mathrm{C}, 5^{\circ} \mathrm{C} / \mathrm{min}$ ramp to $160{ }^{\circ} \mathrm{C}, 20^{\circ} \mathrm{C} / \mathrm{min}$ ramp to $180{ }^{\circ} \mathrm{C}, 3^{\circ} \mathrm{C} / \mathrm{min}$ ramp to $200{ }^{\circ} \mathrm{C}, 20^{\circ} \mathrm{C} / \mathrm{min}$ ramp to $220^{\circ} \mathrm{C}$ and held for $15 \mathrm{~min}$. The carrier gas (hydrogen) flow-rate was $4.0 \mathrm{ml} / \mathrm{min}(0.61 \mathrm{bar})$, measured at $50{ }^{\circ} \mathrm{C}$. Split injection $(1: 40)$ was carried out at $250{ }^{\circ} \mathrm{C}$ and the volume of injection was $1 \mu \mathrm{L}$. Fatty acid identification was made by comparing the relative retention times of FAME peaks from samples with standards. The results were recorded and processed using CSW 1.7 software (DataApex 1.7) (Reis et al., 2011). The results were expressed in relative percentage of each fatty acid.

2.3.5. Phenolic acids composition. The lyophilized samples $(1.5 \mathrm{~g})$ were extracted with methanol:water $(80: 20, \mathrm{v} / \mathrm{v} ; 30 \mathrm{~mL})$ at $-20^{\circ} \mathrm{C}$ for $6 \mathrm{~h}$. After sonication for $15 \mathrm{~min}$, the extract was centrifuged at $4,000 \mathrm{~g}$ for $10 \mathrm{~min}$, and filtered through Whatman $\mathrm{n}^{\circ} 4$ paper. The residue was then extracted with two additional $30 \mathrm{~mL}$ portions of the methanol:water mixture. Combined extracts were evaporated under reduced pressure to remove methanol. The aqueous phase was washed with hexane, and then submitted to a liquid-liquid extraction with diethyl ether $(3 \times 30 \mathrm{~mL})$ and ethyl acetate $(3 \times 30 \mathrm{~mL})$. The organic phases were evaporated to dryness, re-dissolved in water:methanol $(80: 20, \mathrm{v} / \mathrm{v} ; 1 \mathrm{~mL})$, followed by filtering through a $0.22 \mu \mathrm{m}$ disposable LC filter disk. The analysis was performed by HPLC (Shimadzu 20A series UFLC). Detection was carried out in a photodiode array detector (PDA) using $280 \mathrm{~nm}$ as the preferred wavelength (Barros, Dueñas, Ferreira, Baptista \& Santos-Buelga, 2009). The phenolic compounds were characterized according to their UV and mass spectra and retention times, and 
comparison with authentic standards when available. The identified phenolic acids were quantified by comparison of the area of their peaks recorded at $280 \mathrm{~nm}$ with calibration curves obtained from commercial standards of each compound. The results were expressed in $\mu \mathrm{g}$ per $100 \mathrm{~g}$ of dry weight.

2.3.6. Organic acids composition. Lyophilized samples ( $1.5 \mathrm{~g})$ were extracted by stirring with $25 \mathrm{~mL}$ of meta-phosphoric acid $\left(25^{\circ} \mathrm{C}\right.$ at $\left.150 \mathrm{rpm}\right)$ for $45 \mathrm{~min}$ and subsequently filtered through Whatman No. 4 paper. Before analysis by HPLC (equipment mentioned above), the sample was filtered through $0.2 \mu$ m nylon filters. Separation was achieved on a SphereClone (Phenomenex) reverse phase $\mathrm{C}_{18}$ column $(5 \mu \mathrm{m}, 250 \mathrm{~mm} \times 4.6 \mathrm{~mm}$ i.d) thermostatted at $35^{\circ} \mathrm{C}$. The elution was performed with sulphuric acid $3.6 \mathrm{mM}$ using a flow rate of $0.8 \mathrm{~mL} / \mathrm{min}$. Detection was carried out in a PDA, using $215 \mathrm{~nm}$ and 245 as preferred wavelengths (Barros, Pereira \& Ferreira, 2012). The organic acids were quantified by comparison of the area of their peaks recorded at $215 \mathrm{~nm}$ with calibration curves obtained from commercial standards of each compound. The results were expressed in g per $100 \mathrm{~g}$ of dry weight.

\subsection{Preparation of the extract solutions for bioactivity evaluation}

The powdered sample $(20 \mathrm{~g})$ was extracted by stirring with $600 \mathrm{~mL}$ of methanol $\left(25^{\circ} \mathrm{C}\right.$ at $150 \mathrm{rpm}$ ) for $24 \mathrm{~h}$ and subsequently filtered through Whatman No. 4 paper. The extraction procedure was repeated twice at the same conditions. The methanol was evaporated at $40{ }^{\circ} \mathrm{C}$ and the obtained extract was redissolved in: a) methanol for antioxidant activity assays, b) 30\% methanol, sterilized distillated water containing 
$0.02 \%$ Tween 80 and 5\% DMSO for antimicrobial activity assays; at a concentration of $100 \mathrm{mg} / \mathrm{mL}$ (stock solution) and stored at $-20^{\circ} \mathrm{C}$ until further use.

\subsection{Evaluation of antioxidant potential}

2.5.1. General. Successive dilutions were made from the stock solution and submitted to in vitro assays previously described (Reis et al., 2011) to evaluate the antioxidant potential of the samples. The extract concentrations $(\mathrm{mg} / \mathrm{mL})$ providing $50 \%$ of antioxidant activity or 0.5 of absorbance $\left(\mathrm{EC}_{50}\right)$ were calculated from the graphs of antioxidant activity percentages (DPPH, $\beta$-carotene/linoleate and TBARS assays) or absorbance at $690 \mathrm{~nm}$ (reducing power assay) against extract concentrations. Trolox was used as positive control.

2.5.2. Total phenolics. Phenolics were determined by the Folin-Ciocalteu assay using gallic acid to obtain the standard curve $\left(9.4 \times 10^{-3}-1.5 \times 10^{-1} \mathrm{mg} / \mathrm{mL}\right)$, and the results were expressed as mg of gallic acid equivalents (GAE) per g of extract (Reis et al., 2011).

2.5.3. DPPH radical-scavenging activity. DPPH radical-scavenging activity was evaluated by using an ELX800 microplate reader (Bio-Tek Instruments, Inc; Winooski, USA), and calculated as a percentage of DPPH discolouration using the formula: $\left[\left(\mathrm{A}_{\mathrm{DPPH}}-\mathrm{A}_{\mathrm{S}}\right) / \mathrm{A}_{\mathrm{DPPH}}\right] \times 100$, where $A_{\mathrm{S}}$ is the absorbance of the solution containing the sample at $515 \mathrm{~nm}$, and $\mathrm{A}_{\mathrm{DPPH}}$ is the absorbance of the DPPH solution (Reis et al., 2011). 
2.5.4. Reducing power. Reducing power was evaluated by the capacity to convert $\mathrm{Fe}^{3+}$ into $\mathrm{Fe}^{2+}$, measuring the absorbance at $690 \mathrm{~nm}$ in the microplate reader mentioned above. 2.5.5. Inhibition of $\beta$-carotene bleaching. Inhibition of $\beta$-carotene bleaching was evaluated though the $\beta$-carotene/linoleate assay; the neutralization of linoleate free radicals avoids $\beta$-carotene bleaching, which is measured by the formula: $\beta$-carotene absorbance after $2 \mathrm{~h}$ of assay/initial absorbance) $\times 100$ (Reis et al., 2011).

2.5.5. Thiobarbituric acid reactive substances (TBARS) assay. Lipid peroxidation inhibition in porcine (Sus scrofa) brain homogenates was evaluated by the decreasing in TBARS; the colour intensity of the malondialdehyde-thiobarbituric acid (MDA-TBA) was measured by its absorbance at $532 \mathrm{~nm}$; the inhibition ratio (\%) was calculated using the following formula: $[(\mathrm{A}-\mathrm{B}) / \mathrm{A}] \times 100 \%$, where $\mathrm{A}$ and $\mathrm{B}$ were the absorbance of the control and the sample solution, respectively (Reis et al., 2011).

\subsection{Evaluation of antibacterial activity}

Gram-negative bacteria: Escherichia coli (ATCC 35210), Pseudomonas aeruginosa (ATCC 27853), Salmonella typhimurium (ATCC 13311), Salmonella enteritidis (ATCC 13076), Enterobacter cloacae (ATCC 35030); and Gram-positive bacteria: Listeria monocytogenes (NCTC 7973), Staphylococcus aureus (food isolate) were used. The microorganisms were obtained from the Mycological laboratory, Department of Plant Physiology, Institute for biological research "Sinisa Stanković, University of Belgrade, Serbia. 
The minimum inhibitory (MIC) and minimum bactericidal (MBC) concentrations were determined by the microdilution method (Espinel-Ingroff, 2001). Briefly, fresh overnight culture of bacteria was adjusted by the spectrophotometer to a concentration of $1 \times 10^{5}$ $\mathrm{CFU} / \mathrm{mL}$. The requested $\mathrm{CU} / \mathrm{mL}$ corresponded to a bacterial suspension determined in a spectrophotometer at $625 \mathrm{~nm}$ (OD625). Dilutions of inocula were cultured on solid medium to verify the absence of contamination and check the validity of the inoculum. Different solvent dilutions of methanolic extract with or without $0.01 \mathrm{M}$ potassium metabisulfite (E224) were carried out over the wells containing $100 \mu \mathrm{L}$ of Tryptic Soy Broth (TSB) and afterwards, $10 \mu \mathrm{L}$ of inoculum was added to all the wells. The microplates were incubated for $24 \mathrm{~h}$ at $37^{\circ} \mathrm{C}$. The MIC of the samples was detected following the addition of $40 \mu \mathrm{L}$ of iodonitrotetrazolium chloride (INT) $(0.2 \mathrm{mg} / \mathrm{mL})$ and incubation at $37^{\circ} \mathrm{C}$ for $30 \mathrm{~min}$. The lowest concentration that produced a significant inhibition (around 50\%) of the growth of the bacteria in comparison with the positive control was identified as the MIC. The minimum inhibitory concentrations (MICs) obtained from the susceptibility testing of various bacteria to tested extracts were determined also by a colorimetric microbial viability assay based on reduction of a INT color and compared with positive control for each bacterial strains (CSLI, 2006; Tsukatani et al., 2012). MBC was determined by serial sub-cultivation of $10 \mu \mathrm{L}$ into microplates containing $100 \mu \mathrm{L}$ of TSB. The lowest concentration that shows no growth after this sub-culturing was read as the MBC. Standard drugs, namely streptomycin and ampicillin were used as positive controls. $30 \%$ methanol, sterilized distillated water containing $0.02 \%$ Tween 80 and 5\% DMSO were used as negative controls. 


\subsection{In situ preservation of chicken soup}

2.7.1. Isolation and identification of chicken soup contaminant bacterium. Chicken soup used in this study was purchased from the local market. The packaging stated no artificial preservatives. Chicken soup was left open at $25^{\circ} \mathrm{C}$ for 3 days. After that period, the experiment with dilutions was repeated to check for contaminants. Mueller-Hinton (MH) plates were inoculated with different dilutions of chicken soup in sterilized water and kept at $37{ }^{\circ} \mathrm{C}$ in order to investigate possible bacterial contaminants. Bacterial culture reinoculate in Casein soya bean digest broth, homogenise and incubate at $35^{\circ} \mathrm{C}$ to $37{ }^{\circ} \mathrm{C}$ for 18 to $48 \mathrm{~h}$. Subculture on a plate of Bair-Parker agar and incubate at $35^{\circ} \mathrm{C}$ to $37{ }^{\circ} \mathrm{C}$ for 18 to $72 \mathrm{~h}$. Black colonies of gram positive cocci, surrounded by a clear zone indicate the presence of $S$. aureus. After confirmation by suitable biochemical tests such as the coagulase test and the deoxyribonuclease test, the culture was finaly identified by M. Sci. Tatjana Stević (Institute for Medicinal Plant Research "Dr Josif Pančić"), as Staphylococcus aureus and deposited to Bacteria Collection Unit of the Department for Plant Physiology, Institute for Biological Research "Siniša Stanković", Belgrade, Serbia, with the number Sa-DS-12.

2.7.2. In situ antibacterial assay in chicken soup. Chicken soup was prepared in sterile conditions and according to the manufacturer instructions. Different concentrations of the mushroom methanolic extract without or in combination with additive $0.01 \mathrm{M}$ E224 were added to the chicken soup to achieve final concentrations in range of $0.10-10 \mathrm{mg} / \mathrm{mL}$ respectively. The controls contained chicken soup but not mushroom extract. The flasks were homogenized for $30 \mathrm{~s}$ to ensure mixing of the extract compounds with chicken soup. 
The soup mixture was inoculated with $\sim 10^{6}$ cells of foodborne Staphylococcus aureus that had been prepared by growing overnight bacterium at $37^{\circ} \mathrm{C}$ in TSB medium. Cells suspension was adjusted with sterile saline to approximately $1 \times 10^{6}$ cells per $\mathrm{mL}$ of chicken soup. The inoculum was mixed thoroughly with the soup, by hands. Experimental microplates were divided in two groups: one group was kept at $25^{\circ} \mathrm{C}$ and the other at $4{ }^{\circ} \mathrm{C}$. Both groups contained equal amount of mushroom extract. The inhibition percentage at $25^{\circ} \mathrm{C}$ (1) and $4{ }^{\circ} \mathrm{C}$ (2) was calculated by optical density measured by ELISA plate reader (Tecan Austria, GmbH-Austria, Ependorf-AG, Germany) using the following equations:

$$
\begin{gathered}
\text { (1) \% Inhibition }=\left[\frac{(\text { ODsample }- \text { OD } 0 \text { sample })}{(\text { ODgrowth } *-\text { OD } 0 \text { growth } *)}-(\text { ODblank }- \text { OD } 0 \text { blank })\right] \times 100 \\
\text { (2) } \% \text { Inhibition }=\left[\frac{(\text { ODsample }- \text { OD } 0 \text { sample })}{(\text { ODgrowth } *-\text { OD } 0 \text { growth } *)}-(\text { ODblank }- \text { OD } 0 \text { blank })\right] \times 100-\text { Tinhibition }
\end{gathered}
$$

where OD0sample and ODsample corresponded to the absorbance at $612 \mathrm{~nm}$ of the strain growth in the presence of the extract before and after incubation, respectively; OD0blank and ODblank corresponded to the broth medium with dissolved compound before and after incubation, respectively; and OD0growth* and ODgrowth* to the strain growth in the absence of the extract compound before and after incubation at $25{ }^{\circ} \mathrm{C}$, respectively. Tinhibition corresponded to temperature inhibition of $S$. aureus at $4{ }^{\circ} \mathrm{C}$, measured according to the formula (3):

(3) TInhibition $=100-\left(\frac{\text { ODTgrowth } \times 100}{\text { ODT0growth }}\right)$ 
where ODT0growth and ODTgrowth presented the growth of $S$. aureus at $4{ }^{\circ} \mathrm{C}$ in liquid medium, before and after incubation, respectively.

\subsection{Statistical analysis}

Three samples were used but each sample was constituted by three different fruiting bodies. Afterwards, three extracts were prepared from each sample and the assays were also performed in triplicate. The results are expressed as mean values and standard deviation (SD), and analyzed using one-way analysis of variance (ANOVA) followed by Tukey's HSD Test with $\alpha=0.05$. This analysis was carried out using SPSS v. 18.0 program.

\section{Results and Discussion}

According to our knowledge, $T$. pinoyi was chemically analyzed for the first time as well as its antimicrobial preserving properties.

The results of the nutritional value, free sugars and tocopherols composition of Tirmania pinoyi are shown in Table 1. Carbohydrates were the most abundant macronutrients $(82.60 \mathrm{~g} / 100 \mathrm{~g} \mathrm{dw})$, followed by proteins $(8.06 \mathrm{~g} / 100 \mathrm{~g} \mathrm{dw})$. Ash and fat contents were low $(5.26 \mathrm{~g} / 100 \mathrm{~g} \mathrm{dw}$ and $4.09 \mathrm{~g} / 100 \mathrm{~g} \mathrm{dw}$, respectively). The energetic contribution of $T$. pinoyi sample was $2451.20 \mathrm{~kJ} / 100 \mathrm{~g} \mathrm{dw}$. The main free sugars found in this species were trehalose $(1.93 \mathrm{~g} / 100 \mathrm{~g} \mathrm{dw})$ and rhamnose $(1.72 \mathrm{~g} / 100 \mathrm{~g} \mathrm{dw})$, followed by mannitol $(0.31$ $\mathrm{g} / 100 \mathrm{~g} \mathrm{dw})$ and fructose $(0.13 \mathrm{~g} / 100 \mathrm{~g} \mathrm{dw})$. Trehalose as storage carbohydrate and transport sugar has many other biological functions: it can protect animals, plants, and microorganisms from negative environmental impacts, such as nutrition deficiency, 
freezing, hyperosmosis, saline stress, and dehydration, being considered an emergency metabolite (Streeter, 2003; Voita, 2003). Regarding tocopherols, the most abundant isoform was $\beta$-tocopherol $(302.53 \mu \mathrm{g} / 100 \mathrm{~g} \mathrm{dw})$, followed by $\delta$-tocopherol $(252.79$ $\mu \mathrm{g} / 100 \mathrm{~g} \mathrm{dw})$, and $\gamma$-tocopherol $(11.96 \mu \mathrm{g} / 100 \mathrm{~g} \mathrm{dw})$. Tocopherols are the most important natural antioxidants because of their ability to scavenge free radicals, involving a tocopherol-tocopheryl semiquinone redox system. Moreover, tocopherols were shown to exhibit various beneficial effects on degenerative diseases, such as atherosclerosis, cardiovascular disease, Alzheimer's disease, or certain types of cancer (Chan, Stampfer \& Ma, 1999; Keany \& Vita, 1995).

The results considering fatty acids composition of $T$. pinoyi are presented in Table 2 . Saturated fatty acids were the most dominant (SFA, 35.82\% of total FA), followed by monounsaturated fatty acids (MUFA, $33.50 \%$ of total FA) and polyunsaturated fatty acids (PUFA, 30.67\% of total FA). Oleic, linoleic and palmitic acids predominated in the sample $(32.29 \%, 29.72 \%$ and $27.87 \%$ of total FA, respectively). PUFA may protect against several diseases such as cardiovascular, psychiatric, neurological, dermatological and rheumatologic disorders (Rubio-Rodríguez et al., 2010).

The results obtained for organic acids and phenolic compounds in $T$. pinoyi are presented in the Table 3. Among organic acids, citric acid was the most abundant one $(1.26 \mathrm{~g} / 100 \mathrm{~g}$ dw). Regarding phenolic and related compounds, $p$-hydroxibenzoic acid (300.65 $\mu \mathrm{g} / 100$ $\mathrm{g} \mathrm{dw})$ predominated over cinnamic acid $(8.30 \mu \mathrm{g} / 100 \mathrm{~g} \mathrm{dw})$. Phenolic acids are generally considered as good antioxidants; they express antioxidant activity as chelators and free radical scavengers with special impact over hydroxyl and peroxyl radicals, superoxide anions and peroxynitrites (Carocho \& Ferreira, 2013). 
Total phenolics content in the sample methanolic extracts was $13.19 \mathrm{mg}$ GAE/g extract (Table 4). Antioxidant potential, evaluated by four different assays, revealed moderate reducing power of the extract $\left(\mathrm{EC}_{50}=1.80 \mathrm{mg} / \mathrm{mL}\right)$, scavenging of DPPH radicals $\left(\mathrm{EC}_{50}\right.$ $=6.41 \mathrm{mg} / \mathrm{mL})$, inhibition of $\beta$-carotene bleaching $\left(\mathrm{EC}_{50}=28.38 \mathrm{mg} / \mathrm{mL}\right)$ and lipid peroxidation inhibition $\left(\mathrm{EC}_{50}=2.24 \mathrm{mg} / \mathrm{mL}\right)$. The antioxidant activity reported is lower than the one showed by trolox (standard), but the comparison of pure compounds with the extract results should be avoided, because they are individual/purified compounds and not mixtures (in the crude extract the concentration of each individual compound is certainly much lower).

The results of in vitro antibacterial activity of the extract dissolved in different solvents (water, methanol and DMSO), with and without $0.01 \mathrm{M}$ potassium metabisulfite, are given in Table 5.

Regarding the antibacterial activity of $T$. pinoyi extract without E224 it should be highlighted that the extract methanolic solution showed the best activity against all the tested bacteria, except for foodborne $S$. aureus, where extract dissolved in water showed higher antibacterial potential; water and methanolic solutions possessed the same potential against L. monocytogenes. DMSO was the solvent that allowed the lowest activity against all bacteria, except $S$. enteritidis, where this solvent allowed the same activity than water.

Concerning the antibacterial activity of the extract with the addition of commercial preservative E224 it can be noted that the extract dissolved in methanol possessed the best activity against E. coli, E. cloacae and S. enteritidis. Extract dissolved in methanol showed the same activity against foodborn $S$. aureus, L. monocytogenes, P. aeruginosa 
and S. typhimurium, as the extract dissolved in water. Extract dissolved in 5\% DMSO with addition of potassium metabisulfite showed the lowest antibacterial potential. Comparing the activity of antibiotics, streptomycin and ampicillin, with the tested extracts in the presence of commercial preservative potassium metabisulfite, it can be seen that both antibiotics revealed higher antibacterial activity. Nevertheless, the comparison between extracts and pure compounds should be performed with the same precautions mentioned above for antioxidant properties. Other authors previously reported that ethyl acetate extract of the desert edible truffle, T. pinoyi, contains compounds which inhibited the growth of $S$. aureus and B. subtilis, but not of $P$. aeruginosa, E. coli and Enterococcus sp. (assays performed by disc diffusion method) (Dib-Bellahouel \& Fortas, 2011). Mushrooms are a source of naturally occurring antimicrobials, either low molecular weight (LMW) or high molecular weight (HMW) compounds. Examples of antimicrobial active LMW compounds include terpenic compounds, steroids, anthraquinone and benzoic acid derivatives, quinolones and some primary metabolites, such as oxalic acid. HMW compounds that act as antimicrobials include mainly proteins and peptides (Alves et al., 2012). We may presume that antimicrobial activity of the studied species herein might be related to synergy of phenolic and organic acids recorded.

Sulphur additives are reported to provoke some health related problems and in the USA, the Federal Drugs Administration (FDA, 1988) has prohibited their use on raw fruit and vegetables. Potassium metabisulfite is also known as food additive E224. It can cause asthma, cyanosis, faintness and even unconsciousness; it is not recommended to be consumed by children. Nevertheless, it prevents most wild microorganisms from 
growing, and it acts as a potent antioxidant (Khamrui \& Pal, 2004; Rojo-Bezares, Sáenz, Zarazaga, Torres, \& Ruiz-Larrea, 2007). That is why the antimicrobial activity of mushroom extract alone and in combination with E224 was analyzed in chicken soup. The results are presented in the Table 6, being evident that antimicrobial activity of $T$. pinoyi methanolic extract alone against $S$. aureus in chicken soup had better results under refrigerated conditions. Inhibition percentage was quiet constant for all the concentrations used, during period of storage, at temperature of $4{ }^{\circ} \mathrm{C}$ and was in the range of 92.6197.91\%. Considering the same methanolic extract, the inhibition percentage at room temperature was dose dependant; inhibition percentage decreased with lower tested doses of extract. Furthermore, inhibition decreased during the days of storage. The best effect was noticed for the highest concentration used $(5 \mathrm{mg} / \mathrm{mL})$ at $25{ }^{\circ} \mathrm{C}$. A better inhibition was achieved by methanolic extract alone at lower concentrations $(<3 \mathrm{mg} / \mathrm{mL})$ for the first $24 \mathrm{~h}$. Similarly, extended storage ( 48 and $72 \mathrm{~h}$ ) cause reduction in inhibition for both temperatures $\left(4^{\circ} \mathrm{C}\right.$ and $25^{\circ} \mathrm{C}$ ), at $>1 \mathrm{mg} / \mathrm{mL}$ to $3 \mathrm{mg} / \mathrm{mL}$. It could be suggested that $S$. aureus was able to slightly overcome the effect of active compounds from mushroom methanolic extract. This could be correlated to the concentration of the extract used. Considering combination of $0.01 \mathrm{M}$ E224 and methanolic extract, a better effect was achieved in refrigerated conditions when compared to the samples kept at room temperature. The effect was once again dose dependent, decreasing with lower doses and with period of storage. To avoid undesirable sensory changes, toxicity and other harmful and undesirable characteristics, application of low amounts of naturally occurring antimicrobial agents as ingredients should be explored, in order to control spoilage. Research findings from this work provide a basis for developing effective naturally 
occurring antimicrobial agents to extend shelf life of soup and perhaps other types of traditional foods. The irregular and often use of antibiotics contributes to the increase of antibiotic resistance, and the subsequent transmission of these resistances to the environment. The present study provides strong evidence that desert truffle extract might be efficient in the control of Staphylococcus aureus in soup.

In conclusion, $T$. pinoyi proved to have important nutrients (e.g. free sugars and fatty acids), as also bioactive compounds (e.g. tocopherols, phenolic compounds and organic acids) and its methanolic extract showed moderate antioxidant activity including reducing power, free radicals scavenging activity and lipid peroxidation inhibition. In vitro antimicrobial activity of the methanolic extract dissolved in different solvents revealed that sterilized distillated water containing $0.02 \%$ Tween 80 was the most convenient solvent for in situ activity. Methanolic extract successfully inhibited the growth of $S$. aureus in chicken soup, kept at room temperature and in refrigerator, in a dose dependent manner. Overall, the present study provides strong evidence that desert truffle extract might be efficient in the control of Staphylococcus aureus in soup.

\section{Acknowledgements}

The authors are grateful to Foundation for Science and Technology (FCT, Portugal) and COMPETE/QREN/EU for financial support to this work (bilateral cooperation action Portugal/Serbia 2011, research project PTDC/AGR-ALI/110062/2009 and BPD /4609/2008 to L. Barros) and to CIMO (strategic project PEst-OE/AGR/UI0690/2011). 
The authors also thank to Serbian Ministry of Education and Science for financial support (grant number 173032).

\section{References}

Al-Laith, A.A.A. (2010). Antioxidant components and antioxidant, antiradical activities of desert truffle (Tirmania nivea) from various Middle Eastern origins. Journal of Food Composition and Analysis, 23, 15-22.

Alves, M.J., Ferreira I.C.F.R., Dias, J., Teixeira, V., Martins, A., \& Pintado, M. (2012). A review on antimicrobial activity of mushroom (Basidiomycetes) extracts and isolated compounds. Planta Medica, 78, 1-12.

AOAC. (1995). Official methods of analysis (16th Ed.). Arlington VA, USA: Association of Official Analytical Chemists.

Barros, L., Dueñas, M., Ferreira, I.C.F.R., Baptista, P., \& Santos-Buelga C. (2009). Phenolic acids determination by HPLC-DAD-ESI/MS in sixteen different Portuguese wild mushrooms species. Food and Chemical Toxicology, 47, 10761079.

Barros, L., Pereira, C., \& Ferreira, I.C.F.R. (2012). Optimized analysis of organic acids in edible mushrooms from Portugal by ultra fast liquid chromatography and photodiode array detection. Food Analytical Methods, DOI: 10.1007/s12161-012$9443-1$.

Bokhary, M.A., \& Parvez, S. (1992). Soil mycoflora from truffle native areas of Saudi Arabia. Mycopathologia, 118, 103-107. 
Carocho, M., \& Ferreira, I.C.F.R. (2013). A review on antioxidants, prooxidants and related controversy: Natural and synthetic compounds, screening and analysis methodologies and future perspectives. Food and Chemical Toxicology, 51, 1525.

Chan, J.M., Stampfer, M.J., \& Ma, J. (1999). Supplemental vitamin E intake and prostate cancer risk in a large cohort of men in the United States. Cancer Epidemiology, Biomarkers \& Prevention, 8, 893-899.

Clinical and Laboratory Standards Institute. (2009). Methods for dilution antimicrobial susceptibility tests for bacteria that grow aerobically. Approved standard, 8th ed. CLSI publication M07-A8. Clinical and Laboratory Standards Institute, Wayne, PA.

Dabbour, I.R., \& Takruri, H.R. (2002). Protein quality of four types of edible mushrooms found in Jordan. Plant Foods for Human Nutrition, 57, 1-11.

Dib-Bellahouel, S., \& Fortas, Z. (2011). Antibacterial activity of various fractions of ethyl acetate extract from the desert truffle, Tirmania pinoyi, preliminarily analyzed by gas chromatography-mass spectrometry (GC-MS). African Journal of Biotechnology, 10, 9694-9699.

Diez, J., Manjon, J.L., \& Martin, F. (2002). Molecular phylogeny of the mycorrhizal desert truffles (Terfezia and Tirmania), host specificity and edaphic tolerance. Mycologia, 94, 247-259. 
Elinoar, S., \& Volk, T. (2007). Terfezia and Tirmania, desert truffles (terfez, kama, $\mathrm{p} /$ faqa). Delicacies in the sand or manna from Heaven? TomVolkFungi.net

Espinel-Ingroff, A. (2001). Comparation of the E-test with the NCCLS M38-P method for antifungal susceptibility testing of common and emerging pathogenic filamentous fungi. Journal of Clinical Microbiology, 39, 1360-1367.

FDA. 1988. Sulfiting agents: Affirmation of GRAS status. Food and Drug Admin., Fed Reg. 53: 51065-51084.

Hannan, M.A., Al-Dakan, A.A., Aboul-Enein, H.Y., \& Al-Othaimeen, A.A. (1989). Mutagenic and antimutagenic factor(s) extracted from a desert mushroom using different solvents. Mutagen, 4, 111-114.

Heleno, S.A., Barros, L., Sousa, M.J., Martins, A., \& Ferreira, I.C.F.R. (2010). Tocopherols composition of Portuguese wild mushrooms with antioxidant capacity. Food Chemistry, 119, 1443-1450.

Hussain, G., \& Al-Ruqaie, I.M. (1999). Occurrence, chemical composition, and nutritional value of truffles: An overview. Pakistan Journal of Biological Sciences, 2, 510-514.

Janakat, S.M., Al-Fakhiri, S.M., \& Sallal, A.K.J. (2005). Evaluation of antibacterial activity of aqueous and methanolic extracts of the truffle Terfezia claveryi against Pseudomonas aeruginosa. Saudi Medical Journal, 26, 952-955. 
Khamrui, K., \& Pal, D. (2004). Effect of potassium metabisulphite and storage conditions on physico-chemical and microbiological changes in whey-based kinnow juice concentrate. Journal of Food Science and Technology, 41, 401-404.

Keany, J.F. \& Vita, J.A. (1995). Atheriosclerosis, oxidative stress, and antioxidant protection in endothelium-derived relaxing factor action. Progress in Cardiovascular Diseases, 38, 129-154.

Murcia, M.A., Martınez-Tome, M., Jimenez, A.M., Vera, A.M., Honrubia, M., \& Parras, P. (2002). Antioxidant activity of edible fungi (truffles and mushrooms): Losses during industrial processing. Journal of Food Protection, 65, 1614-1622.

Murcia, M.A., Martınez-Tome, M., Vera, A., Morte, A., Gutierrez, A., Honrubia, M., \& Jiménez, A.M. (2003). Effect of industrial processing on desert truffles Terfezia claveryi Chatin and Picoa juniperi Vittadini: proximate composition and fatty acids. Journal of the Science of Food and Agriculture, 83, 535-541.

Pervez-Gilabert, M., Sanchez-Felipe, I., \& Garcia-Carmona, F. (2005). Purification and partial characterization of lipoxygenase from desert truffle (Terfezia claveryi Chatin) ascocarps. Journal of Agricultural and Food Chemistry, 53, 3666-3671.

Reis, F.S., Heleno, S.A., Barros, L., Sousa, M.J., Martins, A., Santos-Buelga, C., \& Ferreira, I.C.F.R. (2011). Toward the antioxidant and chemical characterization of mycorrhizal mushrooms from Northeast Portugal. Journal of Food Science, 76, 824-830. 
Rojo-Bezares, B., Sáenz, Y., Zarazaga, M., Torres, C., \& Ruiz-Larrea, F. (2007). Antimicrobial activity of nisin against Oenococcus oeni and other wine bacteria. International Journal of Food Microbiology, 116, 32-36.

Rougieux, R. (1963). Actions antibiotiques et stimulantes de la truffe du Desert (Terfezia boudieri Chatin). Annales de l'Institut Pasteur, 105, 315-318.

Rubio-Rodríguez, N., Beltrán, S., Jaime, I., de Diego, S. M., Sanz, M.T., \& Rovira Carballido, J. (2010). Production of omega-3 polyunsaturated fatty acid concentrates: a review. Innovative Food Science and Emerging Technologies, 11, $1-12$.

Shavit, T., Volk, T. Terfezia and Tirmania, Desert Truffles (terfez, kama, p/faqa). Delicacies in the sand or manna from Heaven? http://botit.botany.wisc.edu/toms_fungi/jan2007.html.

Streeter, J.G. (2003). Effect of trehalose on survival of Bradyrhizobium japonicum during desiccation. Journal of Applied Microbiology, 95, 484-491.

Tsukatani, T., Suenaga, H., Shiga, M., Noguchi, K., Ishiyama, M., Ezoe, T., \& Matsumoto, K. (2012). Comparison of the WST-8 colorimetric method and the CLSI broth microdilution method for susceptibility testing against drug-resistant bacteria. Journal of Microbiological Methods, 90, 160-166.

Voita, E.O. (2003). Biochemical and genomic regulation of the trehalose cycle in yeast: Review of observations and canonical model analysis. Journal of Theoretical Biology, 223, 55-78. 
Yildiz, A., Yesil, O.F., Yavuz, O., \& Karakaplan, M. (2005). Organic elements and protein in some macrofungi of south east Anatolia in Turkey. Food Chemistry, 89, 605-609. 
Table 1. Nutritional value, free sugars and tocopherols composition of Tirmania pinoyi fruiting bodies (mean $\pm \mathrm{SD}$ ).

\begin{tabular}{|c|c|c|c|c|}
\hline \multicolumn{5}{|c|}{ Nutritional value } \\
\hline $\begin{array}{c}\text { Ash } \\
(\mathrm{g} / 100 \mathrm{~g} \mathrm{dw})\end{array}$ & $\begin{array}{c}\text { Proteins } \\
(\mathrm{g} / 100 \mathrm{~g} \mathrm{dw})\end{array}$ & $\begin{array}{c}\text { Fat } \\
(\mathrm{g} / 100 \mathrm{~g} \mathrm{dw})\end{array}$ & $\begin{array}{l}\text { Carbohydrates } \\
(\mathrm{g} / 100 \mathrm{~g} \mathrm{dw})\end{array}$ & $\begin{array}{c}\text { Energy } \\
(\mathrm{kJ} / 100 \mathrm{~g} \mathrm{dw})\end{array}$ \\
\hline $5.26 \pm 0.04$ & $8.06 \pm 0.79$ & $4.09 \pm 0.20$ & $82.59 \pm 0.85$ & $2451.20 \pm 186.62$ \\
\hline \multicolumn{5}{|c|}{ Free sugars } \\
\hline $\begin{array}{l}\text { Rhamnose } \\
(\mathrm{g} / 100 \mathrm{~g} \mathrm{dw})\end{array}$ & $\begin{array}{c}\text { Fructose } \\
(\mathrm{g} / 100 \mathrm{~g} \mathrm{dw})\end{array}$ & $\begin{array}{c}\text { Trehalose } \\
(\mathrm{g} / 100 \mathrm{~g} \mathrm{dw})\end{array}$ & $\begin{array}{c}\text { Mannitol } \\
(\mathrm{g} / 100 \mathrm{~g} \mathrm{dw})\end{array}$ & $\begin{array}{l}\text { Total sugars } \\
(\mathrm{g} / 100 \mathrm{~g} \mathrm{dw})\end{array}$ \\
\hline $1.72 \pm 0.02$ & $0.13 \pm 0.01$ & $1.93 \pm 0.04$ & $0.31 \pm 0.00$ & $4.09 \pm 0.05$ \\
\hline \multicolumn{5}{|c|}{ Tocopherols } \\
\hline $\begin{array}{l}\alpha \text {-Tocopherol } \\
(\mu \mathrm{g} / 100 \mathrm{~g} \mathrm{dw})\end{array}$ & $\begin{array}{l}\beta \text {-Tocopherol } \\
(\mu \mathrm{g} / 100 \mathrm{~g} \mathrm{dw})\end{array}$ & $\begin{array}{c}\gamma \text {-tocopherol } \\
(\mu \mathrm{g} / 100 \mathrm{~g} \mathrm{dw})\end{array}$ & $\begin{array}{l}\delta \text {-Tocopherol } \\
(\mu \mathrm{g} / 100 \mathrm{~g} \mathrm{dw})\end{array}$ & $\begin{array}{l}\text { Total tocopherols } \\
(\mu \mathrm{g} / 100 \mathrm{~g} \mathrm{dw})\end{array}$ \\
\hline nd & $302.53 \pm 2.15$ & $11.96 \pm 3.39$ & $252.79 \pm 8.02$ & $567.29 \pm 13.57$ \\
\hline
\end{tabular}


Table 2. Fatty acids composition (relative percentage \%) of Tirmania pinoyi fruiting bodies (mean $\pm \mathrm{SD}$ ).

\begin{tabular}{|c|c|c|c|}
\hline \multicolumn{4}{|c|}{ Fatty acids } \\
\hline C6:0 & $1.89 \pm 0.00$ & $\mathrm{C} 18: 3 \mathrm{n} 3$ & $0.20 \pm 0.01$ \\
\hline $\mathrm{C} 8: 0$ & $0.23 \pm 0.00$ & $\mathrm{C} 20: 0$ & $0.22 \pm 0.00$ \\
\hline $\mathrm{C} 10: 0$ & $0.01 \pm 0.00$ & $\mathrm{C} 20: 1$ & $0.38 \pm 0.01$ \\
\hline C12:0 & $0.04 \pm 0.00$ & $\mathrm{C} 20: 2$ & $0.14 \pm 0.00$ \\
\hline C13:0 & $0.06 \pm 0.00$ & $\mathrm{C} 20: 3 \mathrm{n} 3+\mathrm{C} 21: 0$ & $0.36 \pm 0.00$ \\
\hline C14:0 & $0.21 \pm 0.01$ & $\mathrm{C} 20: 5 \mathrm{n} 3$ & $0.25 \pm 0.01$ \\
\hline $\mathrm{C} 15: 0$ & $0.16 \pm 0.00$ & $\mathrm{C} 22: 0$ & $1.01 \pm 0.03$ \\
\hline C16:0 & $27.87 \pm 0.27$ & $\mathrm{C} 22: \ln 9$ & $0.11 \pm 0.00$ \\
\hline C16:1 & $0.64 \pm 0.01$ & $\mathrm{C} 23: 0$ & $0.19 \pm 0.03$ \\
\hline $\mathrm{C} 17: 0$ & $0.37 \pm 0.03$ & $\mathrm{C} 24: 0$ & $0.89 \pm 0.09$ \\
\hline $\mathrm{C} 18: 0$ & $2.68 \pm 0.03$ & $\mathrm{C} 24: 1$ & $0.09 \pm 0.03$ \\
\hline $\mathrm{C} 18: \ln 9$ & $32.29 \pm 0.04$ & Total SFA ( $\%$ of total FA) & $35.82 \pm 0.08$ \\
\hline $\mathrm{C} 18: 2 \mathrm{n} 6$ & $29.72 \pm 0.07$ & Total MUFA ( $\%$ of total FA) & $33.50 \pm 0.01$ \\
\hline & & Total PUFA ( $\%$ of total FA) & $30.67 \pm 0.07$ \\
\hline
\end{tabular}

C6:0 (Caproic acid); C8:0 (Caprylic acid); C10:0 (Capric acid); C12:0 (Lauric acid); C13:0 (Tridecanoic acid); C14:0 (Myristic acid); C15:0 (Pentadecanoic acid); C16:0 (Palmitic acid); C16:1 (Palmitoleic acid); C17:0 (Heptadecanoic acid); C18:0 (Stearic acid); C18:1n9c (Oleic acid); C18:2n6c (Linoleic acid); C18:3n3 (Linolenic acid); C20:0 (Arachidic acid); C20:1 (cis-11-Eicosenoic acid); C20:2 (cis-11,14-Eicosadienoic acid); C20:3n3+C21:0 (cis-11,14,17-Eicosatrienoic acid and Heneicosanoic acid); C20:5n3 (cis-5,8,11,14,17-Eicosapentaenoic acid); C22:0 (Behenic acid); C22:1n9 (Erucic acid); C23:0 (Tricosanoic acid); C24:0 (Lignoceric acid); C24:1 (Nervonic acid). SFAsaturated fatty acids; MUFA- monounsaturated fatty acids; PUFA- polyunsaturated fatty acids; FA- fatty acid. 
Table 3. Organic acids and phenolic acids in Tirmania pinoyi fruiting bodies (mean \pm SD).

Organic acids $\quad$ Phenolic acids

\begin{tabular}{llll}
\hline $\begin{array}{l}\text { Quinic acid } \\
(\mathrm{g} / 100 \mathrm{~g} \mathrm{dw})\end{array}$ & $0.83 \pm 0.15$ & $\begin{array}{l}p \text {-Hydroxybenzoic acid } \\
(\mu \mathrm{g} / 100 \mathrm{~g} \mathrm{dw})\end{array}$ & $300.65 \pm 9.92$ \\
Malic acid & $0.35 \pm 0.01$ & $\begin{array}{l}\text { Cinnamic acid } \\
(\mu \mathrm{g} / 100 \mathrm{~g} \mathrm{dw})\end{array}$ & $8.30 \pm 0.55$ \\
$(\mathrm{~g} / 100 \mathrm{~g} \mathrm{dw})$ & & & \\
Fumaric acid & $0.05 \pm 0.00$ & & \\
$(\mathrm{~g} / 100 \mathrm{~g} \mathrm{dw})$ & $1.26 \pm 0.03$ & & \\
Citric acid & & \\
$(\mathrm{g} / 100 \mathrm{~g} \mathrm{dw})$ & & & \\
\hline
\end{tabular}


Table 4. Antioxidant activity of Tirmania pinoyi methanolic extract (mean \pm SD).

\section{Antioxidant activity}

Total Phenolics

(mg GAE/g extract)

$13.19 \pm 0.18$

Reducing power

$\left(\mathrm{EC}_{50} ; \mathrm{mg} / \mathrm{mL}\right)$

$1.80 \pm 0.01$

DPPH radical-scavenging activity

$\left(\mathrm{EC}_{50} ; \mathrm{mg} / \mathrm{mL}\right)$

$$
6.41 \pm 0.16
$$

$\beta$-carotene bleaching inhibition

$\left(\mathrm{EC}_{50} ; \mathrm{mg} / \mathrm{mL}\right)$

$28.38 \pm 0.53$

TBARS inhibition

$\left(\mathrm{EC}_{50} ; \mathrm{mg} / \mathrm{mL}\right)$

$\mathrm{EC}_{50}$ : Extract concentration corresponding to $50 \%$ of antioxidant activity or 0.5 of absorbance for the reducing power assay. GAE means gallic acid equivalents. Concerning the total phenolics assay, higher values mean higher reducing power; for the other assays, the results are presented in $\mathrm{EC}_{50}$ values, what means that lower values correspond to higher reducing power or antioxidant potential. Trolox $\mathrm{EC}_{50}$ values: $30 \mu \mathrm{g} / \mathrm{mL}$ (reducing power), $43 \mu \mathrm{g} / \mathrm{mL}$ (DPPH scavenging activity), $3 \mu \mathrm{g} / \mathrm{mL}$ ( $\beta$-carotene bleaching inhibition) and $4 \mu \mathrm{g} / \mathrm{mL}$ (TBARS inhibition). 
Table 5. Antibacterial activities of Tirmania pinoyi methanolic extract with and without potassium metabisulfite (I) dissolved in different solvents $(\mathrm{mg} / \mathrm{mL})$.

\begin{tabular}{|c|c|c|c|c|c|c|c|c|}
\hline & Bacteria $\rightarrow$ & S. aureus & L. monocytogenes & P. aeruginosa & E. coli & E. cloacae & S. tiphymurium & S. enteritidis \\
\hline \multirow{2}{*}{ Water } & MIC & $2.50^{\mathrm{d}}$ & $10.00^{\mathrm{b}}$ & $20.00^{\mathrm{b}}$ & $15.00^{\mathrm{b}}$ & $20.00^{\mathrm{b}}$ & $20.00^{\mathrm{b}}$ & $5.00^{\mathrm{a}}$ \\
\hline & $\mathrm{MBC}$ & $5.00^{\mathrm{c}}$ & $15.00^{\mathrm{b}}$ & $30.00^{\mathrm{b}}$ & $30.00^{\mathrm{b}}$ & $30.00^{\mathrm{b}}$ & $30.00^{\mathrm{b}}$ & $10.00^{\mathrm{a}}$ \\
\hline \multirow{2}{*}{ Water + I } & MIC & $2.00^{\mathrm{e}}$ & $1.50^{\mathrm{d}}$ & $1.50^{\mathrm{e}}$ & $1.50^{\mathrm{d}}$ & $2.00^{\mathrm{e}}$ & $1.50^{\mathrm{e}}$ & $1.50^{\mathrm{d}}$ \\
\hline & MBC & $2.50^{\mathrm{d}}$ & $2.00^{\mathrm{d}}$ & $2.00^{\mathrm{e}}$ & $2.00^{\mathrm{e}}$ & $2.50^{\mathrm{e}}$ & $2.00^{\mathrm{e}}$ & $2.00^{\mathrm{d}}$ \\
\hline \multirow{2}{*}{$30 \%$ Methanol } & MIC & $5.00^{\mathrm{b}}$ & $10.00^{\mathrm{b}}$ & $15.00^{\mathrm{c}}$ & $15.00^{\mathrm{b}}$ & $15.00^{\mathrm{c}}$ & $15.00^{\mathrm{c}}$ & $2.50^{\mathrm{c}}$ \\
\hline & MBC & $10.00^{\mathrm{b}}$ & $15.00^{\mathrm{b}}$ & $20.00^{\mathrm{c}}$ & $20.00^{\mathrm{c}}$ & $20.00^{\mathrm{c}}$ & $20.00^{\mathrm{c}}$ & $5.00^{\mathrm{c}}$ \\
\hline \multirow{2}{*}{$30 \%$ Methanol + I } & MIC & $2.00^{\mathrm{e}}$ & $1.50^{\mathrm{d}}$ & $1.50^{\mathrm{e}}$ & $1.00^{\mathrm{f}}$ & $1.50^{\mathrm{f}}$ & $1.50^{\mathrm{e}}$ & $1.00^{\mathrm{e}}$ \\
\hline & MBC & $2.50^{\mathrm{d}}$ & $2.00^{\mathrm{d}}$ & $2.00^{\mathrm{f}}$ & $1.50^{\mathrm{f}}$ & $2.00^{\mathrm{f}}$ & $2.00^{\mathrm{e}}$ & $1.50^{\mathrm{e}}$ \\
\hline \multirow{2}{*}{$5 \%$ DMSO } & MIC & $20.00^{\mathrm{a}}$ & $20.00^{\mathrm{a}}$ & $30.00^{\mathrm{a}}$ & $30.00^{\mathrm{a}}$ & $30.00^{\mathrm{a}}$ & $30.00^{\mathrm{a}}$ & $5.00^{\mathrm{a}}$ \\
\hline & $\mathrm{MBC}$ & $30.00^{\mathrm{a}}$ & $30.00^{\mathrm{a}}$ & $40.00^{\mathrm{a}}$ & $40.00^{\mathrm{a}}$ & $40.00^{\mathrm{a}}$ & $40.00^{\mathrm{a}}$ & $10.00^{\mathrm{a}}$ \\
\hline \multirow[t]{2}{*}{$5 \%$ DMSO + I } & MIC & $4.00^{\mathrm{c}}$ & $3.00^{\mathrm{c}}$ & $4.00^{\mathrm{d}}$ & $4.00^{\mathrm{c}}$ & $3.00^{\mathrm{d}}$ & $5.00^{\mathrm{d}}$ & $3.00^{\mathrm{b}}$ \\
\hline & MBC & $5.00^{\mathrm{c}}$ & $4.00^{\mathrm{c}}$ & $5.00^{\mathrm{d}}$ & $5.00^{\mathrm{d}}$ & $4.00^{\mathrm{d}}$ & $6.00^{\mathrm{d}}$ & $4.00^{\mathrm{b}}$ \\
\hline \multirow[t]{2}{*}{ Streptomycin } & MIC & $0.05^{\mathrm{f}}$ & $0.50^{\mathrm{e}}$ & $0.05^{\mathrm{f}}$ & $0.10^{\mathrm{g}}$ & $0.05^{\mathrm{h}}$ & $0.10^{\mathrm{f}}$ & $0.10^{\mathrm{f}}$ \\
\hline & MBC & $0.10^{\mathrm{e}}$ & $0.50^{\mathrm{e}}$ & $0.10^{\mathrm{f}}$ & $0.10^{\mathrm{g}}$ & $0.10^{\mathrm{h}}$ & $0.20^{\mathrm{f}}$ & $0.40^{\mathrm{f}}$ \\
\hline \multirow[t]{2}{*}{ Ampicillin } & MIC & $0.10^{\mathrm{f}}$ & $0.10^{\mathrm{e}}$ & $0.15^{\mathrm{f}}$ & $0.10^{\mathrm{g}}$ & $0.30^{\mathrm{g}}$ & $0.10^{\mathrm{f}}$ & $0.10^{\mathrm{f}}$ \\
\hline & MBC & $0.15^{\mathrm{e}}$ & $0.15^{\mathrm{f}}$ & $0.30^{\mathrm{f}}$ & $0.15^{\mathrm{g}}$ & $0.50^{\mathrm{g}}$ & $0.20^{\mathrm{f}}$ & $0.20^{\mathrm{g}}$ \\
\hline
\end{tabular}

In each column, and for MIC or MBC values, different letters mean significant differences between samples $(p<0.05)$. 
Table 6. Antibacterial activity of Tirmania pinoyi methanolic extract alone and in combination with $0.01 \mathrm{M}$ potassium metabisulfite (I) in soup, against foodborne Staphylococcus aureus (mean $\pm \mathrm{SD}$ )

\begin{tabular}{|c|c|c|c|c|c|c|}
\hline \multirow{2}{*}{ Concentration } & \multirow{2}{*}{ Extract } & \multirow{2}{*}{ Temp. } & \multicolumn{4}{|c|}{ Percentage of inhibition of $S$. aureus in chicken soup } \\
\hline & & & $0 \mathrm{~h}$ & $24 \mathrm{~h}$ & $48 \mathrm{~h}$ & $72 \mathrm{~h}$ \\
\hline \multirow{2}{*}{$5.00 \mathrm{mg} / \mathrm{mL}$} & $\mathrm{MeOH}+\mathrm{I}$ & $\begin{array}{l}+25^{\circ} \mathrm{C} \\
+4{ }^{\circ} \mathrm{C}\end{array}$ & $\begin{array}{l}0.00 \pm 0.00 \\
0.00 \pm 0.00\end{array}$ & $\begin{array}{l}97.46 \pm 0.87^{\mathrm{a}} \\
97.88 \pm 2.33^{\mathrm{a}}\end{array}$ & $\begin{array}{c}99.09 \pm 1.55^{\mathrm{a}} \\
96.70 \pm 1.47^{\mathrm{ba}}\end{array}$ & $\begin{array}{c}99.03 \pm 0.83^{\mathrm{a}} \\
96.07 \pm 0.72^{\mathrm{ba}}\end{array}$ \\
\hline & $\mathrm{MeOH}$ & $\begin{array}{l}+25^{\circ} \mathrm{C} \\
+4{ }^{\circ} \mathrm{C}\end{array}$ & $\begin{array}{l}0.00 \pm 0.00 \\
0.00 \pm 0.00\end{array}$ & $\begin{array}{l}97.07 \pm 2.04^{\mathrm{a}} \\
95.81 \pm 0.86^{\mathrm{b}}\end{array}$ & $\begin{array}{l}98.21 \pm 1.41^{\mathrm{a}} \\
93.93 \pm 4.71^{\mathrm{a}}\end{array}$ & $\begin{array}{l}96.30 \pm 2.49^{\mathrm{a}} \\
97.54 \pm 0.64^{\mathrm{a}}\end{array}$ \\
\hline \multirow{2}{*}{$4.00 \mathrm{mg} / \mathrm{mL}$} & $\mathrm{MeOH}+\mathrm{I}$ & $\begin{array}{l}+25^{\circ} \mathrm{C} \\
+4{ }^{\circ} \mathrm{C}\end{array}$ & $\begin{array}{l}0.00 \pm 0.00 \\
0.00 \pm 0.00\end{array}$ & $\begin{array}{c}98.43 \pm 0.53^{\mathrm{a}} \\
93.52 \pm 1.18^{\mathrm{ba}}\end{array}$ & $\begin{array}{c}97.26 \pm 0.67^{\mathrm{a}} \\
95.97 \pm 1.33^{\mathrm{ba}}\end{array}$ & $\begin{array}{l}96.17 \pm 1.02^{b a} \\
95.47 \pm 1.89^{b a}\end{array}$ \\
\hline & $\mathrm{MeOH}$ & $\begin{array}{l}+25^{\circ} \mathrm{C} \\
+4{ }^{\circ} \mathrm{C}\end{array}$ & $\begin{array}{l}0.00 \pm 0.00 \\
0.00 \pm 0.00\end{array}$ & $\begin{array}{l}95.29 \pm 4.37^{\mathrm{a}} \\
95.03 \pm 0.89^{\mathrm{a}}\end{array}$ & $\begin{array}{l}95.06 \pm 3.95^{\mathrm{a}} \\
95.48 \pm 1.21^{\mathrm{a}}\end{array}$ & $\begin{array}{l}69.27 \pm 3.74^{\mathrm{b}} \\
97.71 \pm 0.35^{\mathrm{a}}\end{array}$ \\
\hline \multirow{2}{*}{$3.00 \mathrm{mg} / \mathrm{mL}$} & $\mathrm{MeOH}+\mathrm{I}$ & $\begin{array}{l}+25^{\circ} \mathrm{C} \\
+4{ }^{\circ} \mathrm{C}\end{array}$ & $\begin{array}{l}0.00 \pm 0.00 \\
0.00 \pm 0.00\end{array}$ & $\begin{array}{l}97.74 \pm 2.30^{\mathrm{a}} \\
96.52 \pm 1.00^{\mathrm{a}}\end{array}$ & $\begin{array}{l}98.54 \pm 0.84^{\mathrm{a}} \\
98.27 \pm 0.20^{\mathrm{a}}\end{array}$ & $\begin{array}{c}88.59 \pm 10.58^{\mathrm{b}} \\
97.61 \pm 0.98^{\mathrm{a}}\end{array}$ \\
\hline & $\mathrm{MeOH}$ & $\begin{array}{l}+25^{\circ} \mathrm{C} \\
+4{ }^{\circ} \mathrm{C}\end{array}$ & $\begin{array}{l}0.00 \pm 0.00 \\
0.00 \pm 0.00\end{array}$ & $\begin{array}{l}93.21 \pm 2.23^{\mathrm{a}} \\
97.24 \pm 0.63^{\mathrm{a}}\end{array}$ & $\begin{array}{l}45.87 \pm 6.82^{\mathrm{b}} \\
93.81 \pm 1.60^{\mathrm{a}}\end{array}$ & $\begin{array}{l}20.69 \pm 2.56^{\mathrm{c}} \\
97.91 \pm 0.00^{\mathrm{a}}\end{array}$ \\
\hline \multirow{2}{*}{$2.00 \mathrm{mg} / \mathrm{mL}$} & $\mathrm{MeOH}+\mathrm{I}$ & $\begin{array}{l}+25^{\circ} \mathrm{C} \\
+4{ }^{\circ} \mathrm{C}\end{array}$ & $\begin{array}{l}0.00 \pm 0.00 \\
0.00 \pm 0.00\end{array}$ & $\begin{array}{c}36.36 \pm 4.61^{\mathrm{c}} \\
90.71 \pm 1.79^{\mathrm{ba}}\end{array}$ & $\begin{array}{c}8.34 \pm 5.20^{\mathrm{d}} \\
98.15 \pm 0.42^{\mathrm{a}}\end{array}$ & $\begin{array}{l}13.12 \pm 14.04^{d} \\
96.94 \pm 1.09^{\text {ba }}\end{array}$ \\
\hline & $\mathrm{MeOH}$ & $\begin{array}{l}+25^{\circ} \mathrm{C} \\
+4{ }^{\circ} \mathrm{C}\end{array}$ & $\begin{array}{l}0.00 \pm 0.00 \\
0.00 \pm 0.00\end{array}$ & $\begin{array}{l}70.43 \pm 6.55^{\mathrm{b}} \\
96.70 \pm 1.13^{\mathrm{a}}\end{array}$ & $\begin{array}{l}16.99 \pm 2.14^{\mathrm{c}} \\
95.14 \pm 1.00^{\mathrm{a}}\end{array}$ & $\begin{array}{l}14.92 \pm 2.89^{\mathrm{d}} \\
97.91 \pm 0.00^{\mathrm{a}}\end{array}$ \\
\hline \multirow{2}{*}{$1.00 \mathrm{mg} / \mathrm{mL}$} & $\mathrm{MeOH}+\mathrm{I}$ & $\begin{array}{l}+25^{\circ} \mathrm{C} \\
+4{ }^{\circ} \mathrm{C}\end{array}$ & $\begin{array}{l}0.00 \pm 0.00 \\
0.00 \pm 0.00\end{array}$ & $\begin{array}{l}17.00 \pm 2.01^{\mathrm{d}} \\
88.45 \pm 2.37^{\mathrm{b}}\end{array}$ & $\begin{array}{l}6.40 \pm 6.26^{\mathrm{ed}} \\
86.78 \pm 1.72^{\mathrm{b}}\end{array}$ & $\begin{array}{l}12.06 \pm 5.46^{\mathrm{f}} \\
86.83 \pm 2.20^{\mathrm{b}}\end{array}$ \\
\hline & $\mathrm{MeOH}$ & $\begin{array}{l}+25^{\circ} \mathrm{C} \\
+4{ }^{\circ} \mathrm{C}\end{array}$ & $\begin{array}{l}0.00 \pm 0.00 \\
0.00 \pm 0.00\end{array}$ & $\begin{array}{l}16.23 \pm 3.13^{\mathrm{c}} \\
97.06 \pm 0.54^{\mathrm{a}}\end{array}$ & $\begin{array}{l}12.30 \pm 3.00^{\mathrm{d}} \\
92.61 \pm 3.86^{\mathrm{a}}\end{array}$ & $\begin{array}{c}9.06 \pm 0.53^{\mathrm{e}} \\
96.70 \pm 2.09^{\mathrm{a}}\end{array}$ \\
\hline \multirow{2}{*}{$0.50 \mathrm{mg} / \mathrm{mL}$} & $\mathrm{MeOH}+\mathrm{I}$ & $\begin{array}{l}+25^{\circ} \mathrm{C} \\
+4{ }^{\circ} \mathrm{C}\end{array}$ & $\begin{array}{l}0.00 \pm 0.00 \\
0.00 \pm 0.00\end{array}$ & $\begin{array}{l}13.51 \pm 4.19^{\mathrm{e}} \\
83.40 \pm 4.21^{\mathrm{b}}\end{array}$ & $\begin{array}{c}7.31 \pm 4.84^{\mathrm{d}} \\
87.91 \pm 1.89^{\mathrm{b}}\end{array}$ & $\begin{array}{l}13.46 \pm 5.46^{\mathrm{e}} \\
84.59 \pm 1.69^{\mathrm{b}}\end{array}$ \\
\hline & $\mathrm{MeOH}$ & $\begin{array}{l}+25^{\circ} \mathrm{C} \\
+4{ }^{\circ} \mathrm{C}\end{array}$ & $\begin{array}{l}0.00 \pm 0.00 \\
0.00 \pm 0.00\end{array}$ & $\begin{array}{l}12.11 \pm 3.69^{\mathrm{d}} \\
94.84 \pm 2.04^{\mathrm{a}}\end{array}$ & $\begin{array}{l}10.93 \pm 2.11^{\mathrm{e}} \\
95.65 \pm 0.98^{\mathrm{a}}\end{array}$ & $\begin{array}{c}5.48 \pm 0.85^{\mathrm{f}} \\
97.41 \pm 0.87^{\mathrm{a}}\end{array}$ \\
\hline \multirow{2}{*}{$0.25 \mathrm{mg} / \mathrm{mL}$} & $\mathrm{MeOH}+\mathrm{I}$ & $\begin{array}{l}+25^{\circ} \mathrm{C} \\
+4{ }^{\circ} \mathrm{C}\end{array}$ & $\begin{array}{l}0.00 \pm 0.00 \\
0.00 \pm 0.00\end{array}$ & $\begin{array}{c}3.56 \pm 3.20^{\mathrm{g}} \\
84.52 \pm 13.69^{\mathrm{b}}\end{array}$ & $\begin{array}{c}5.43 \pm 2.18^{\mathrm{e}} \\
87.05 \pm 7.37^{\mathrm{b}}\end{array}$ & $\begin{array}{l}14.53 \pm 1.55^{\mathrm{e}} \\
82.94 \pm 5.77^{\mathrm{b}}\end{array}$ \\
\hline & $\mathrm{MeOH}$ & $\begin{array}{l}+25^{\circ} \mathrm{C} \\
+4{ }^{\circ} \mathrm{C}\end{array}$ & $\begin{array}{l}0.00 \pm 0.00 \\
0.00 \pm 0.00\end{array}$ & $\begin{array}{c}3.81 \pm 3.42^{\mathrm{e}} \\
97.42 \pm 0.32^{\mathrm{a}}\end{array}$ & $\begin{array}{c}8.55 \pm 1.69^{\mathrm{f}} \\
95.04 \pm 1.99^{\mathrm{a}}\end{array}$ & $\begin{array}{c}4.89 \pm 1.58^{\mathrm{f}} \\
97.21 \pm 1.21^{\mathrm{a}}\end{array}$ \\
\hline \multirow{2}{*}{$0.13 \mathrm{mg} / \mathrm{mL}$} & $\mathrm{MeOH}+\mathrm{I}$ & $\begin{array}{l}+25^{\circ} \mathrm{C} \\
+4{ }^{\circ} \mathrm{C}\end{array}$ & $\begin{array}{l}0.00 \pm 0.00 \\
0.00 \pm 0.00\end{array}$ & $\begin{array}{l}4.51 \pm 3.70^{\mathrm{gf}} \\
88.11 \pm 2.37^{\mathrm{b}}\end{array}$ & $\begin{array}{c}3.88 \pm 0.58^{\mathrm{f}} \\
74.02 \pm 1.78^{\mathrm{c}}\end{array}$ & $\begin{array}{l}14.47 \pm 7.48^{\mathrm{e}} \\
73.50 \pm 3.76^{\mathrm{c}}\end{array}$ \\
\hline & $\mathrm{MeOH}$ & $\begin{array}{l}+25^{\circ} \mathrm{C} \\
+4{ }^{\circ} \mathrm{C}\end{array}$ & $\begin{array}{l}0.00 \pm 0.00 \\
0.00 \pm 0.00\end{array}$ & $\begin{array}{c}3.62 \pm 1.17^{\mathrm{e}} \\
97.41 \pm 0.33^{\mathrm{a}}\end{array}$ & $\begin{array}{c}5.27 \pm 1.45^{\mathrm{g}} \\
95.42 \pm 2.13^{\mathrm{a}}\end{array}$ & $\begin{array}{c}0.58 \pm 0.22^{\mathrm{g}} \\
97.34 \pm 0.99^{\mathrm{a}}\end{array}$ \\
\hline
\end{tabular}

In each column, and for each concentration, different letters mean significant differences between samples $(p<0.05)$. 